This item was submitted to Loughborough's Research Repository by the author.

Items in Figshare are protected by copyright, with all rights reserved, unless otherwise indicated.

\title{
Blurring the boundaries: Fourteen great detective stories and Joyce's a portrait of the artist as a young man in the modern library series
}

\section{PLEASE CITE THE PUBLISHED VERSION}

http://dx.doi.org/10.1353/jjq.2013.0007

\section{PUBLISHER}

(c) University of Tulsa

\section{VERSION}

AM (Accepted Manuscript)

\section{PUBLISHER STATEMENT}

This work is made available according to the conditions of the Creative Commons Attribution-NonCommercialNoDerivatives 4.0 International (CC BY-NC-ND 4.0) licence. Full details of this licence are available at: https://creativecommons.org/licenses/by-nc-nd/4.0/

\section{LICENCE}

CC BY-NC-ND 4.0

\section{REPOSITORY RECORD}

Jaillant, Lise. 2019. "Blurring the Boundaries: Fourteen Great Detective Stories and Joyce's a Portrait of the Artist as a Young Man in the Modern Library Series". figshare. https://hdl.handle.net/2134/20555. 


\section{Lise Jaillant}

Blurring the Boundaries: Fourteen Great Detective Stories and Joyce's A Portrait of the Artist as a Young Man in the Modern Library Series. ${ }^{1}$

[This is the author's version. The final version was published in James Joyce Quarterly 50.3 (2013): 767-95].

In March 1928, the Modern Library, a uniform series of reprints marketed as "the world's best books," added two new titles - Fourteen Great Detective Stories and James Joyce's A Portrait of the Artist as a Young Man. While reprints were generally not reviewed in periodicals, the cheap price and stylish presentation of the Modern Library attracted plenty of attention. For example, the Hartford Courant published a review that praised these additions to a "remarkable series." ${ }^{2}$ For today's reader, it seems surprising that Joyce's text could be reviewed in a few sentences after a lengthy discussion on detective tales. The "great divide" between modernism and mass culture, described by Andreas Huyssen, conveys the impression of two radically different cultural spheres even if recent scholarship has traced the influence of popular culture on many modernist works. ${ }^{3}$ Despite this increasing interest in the intersections between the "high" and the "low," most scholars have failed to notice that modernist and detective texts were often published in the same venues. ${ }^{4}$ Indeed, in the late 1920s and early 1930s, many mainstream firms issued texts that we now see as "high modernist," alongside detective fiction. For instance, the renowned publisher Alfred Knopf released Dashiell Hammett's Red Harvest, The Dain Curse and The Maltese Falcon in 1929 and 1930 (the latter was then reprinted in the Modern Library). Knopf's list also included D. H. Lawrence, Ezra Pound, Katherine Mansfield and Langston Hughes. Moreover, in 1928, Scribner's Magazine serialized S. S. Van Dine's The Greene Murder Case. The fact that Scribner, the publisher of Fitzgerald and Hemingway, could proudly endorse Van Dine's story shows that popular culture and literary modernism were increasingly intertwined. Drawing on extensive research in the Random House archives at Columbia Rare Book \& Manuscript Library, this article 
uses a book history approach to show that the Modern Library contributed to the blurring of boundaries between modernist and popular fiction. ${ }^{5}$

When Albert Boni and Horace Liveright created the Modern Library series in New York in 1917, their objective was to offer modern "classics" at an affordable price. One of the first advertisement for the new series thus claimed: "It is the purpose of the publishers to issue in the 'Modern Library' modern books that have won for themselves a position as classics." ${ }^{\circ}$ Unlike Everyman's Library and other uniform series of reprints, the Modern Library owners did not limit their list to out-of-copyright works. They believed that recent titles marketed as distinguished "classics" would find a large audience. "The 'Modern Library' appeals to people who consider good books a necessity, not a luxury," declared the same ad. "People are judged by the books they read" (emphasis in the original). Since books, like other consumer products, could be used as status markers, the Modern Library thrived to be associated with taste, audacity and modernity. The first list included many controversial titles, such as H. G. Wells's Ann Veronica, Guy de Maupassant's Mademoiselle Fifi, Gustave Flaubert's Madame Bovary and Oscar Wilde's Dorian Gray. The much more conservative Everyman's Library would wait until 1928 to include Madame Bovary and until 1930 to add Wilde's writings. In short, the Modern Library was the first uniform series to sell a broadly defined modern literature to a large audience.

By the late 1920s, the Modern Library had become a key player in the field of book production. None of its competitors offered the same mix of cheapness, distinction and modernity, along with an extensive distribution network. As Jay Satterfield has shown, "a Grosset \& Dunlap reprint was simply an inexpensive version of the original title," while the Modern Library was designed "to be something more, an entity beyond the original work, as an integral part of a recognizable series with its own established reputation for excellence."7 Knopf Pocket Books series was well produced and cheap, but "lacked both the Modern Library's distribution system and advertising budget" (139). And Everyman's Library was simply not modern enough to threaten the Modern Library's unique positioning. In March 1928, an advertisement in Publishers' Weekly 
celebrated the expansion of the series: "497,127 sales in 1927 - a gain of 107,532 over 1926." At the bottom of the page, below a list of recent publications that included Joyce's novel and the collection of detective stories, the Modern Library's ambition for 1928 appeared in capital letters: "TOWARDS OUR MILLION-A-YEAR GOAL." 8 The Modern Library thus combined a distinguished list with a fierce determination to seize commercial opportunities and increase its market share.

This article positions A Portrait of the Artist as a Young Man and Fourteen Great Detective Stories in the literary field of the late 1920s, at the time when many modernist texts were sufficiently well-known to be included in a cheap series of classics, but had not yet been dissociated from "lesser" kinds of literature. The readers of 1928 were well aware that Portrait of the Artist and the detective stories had not the same style and narrative pattern. But the fact that these texts were included in a uniform series shows that the boundaries between "modernist" and "popular" literatures were not so entrenched in the interwar period. This essay is organized into three parts: "marketing," "reviewing" and "dividing." While the first two parts focus mainly on the year 1928, the third part examines the widening of the divide between literary modernism and detective fiction after the Second World War.

\section{I) Marketing}

It is important to note that the Modern Library editions of Portrait of the Artist and Fourteen Great Detective Stories shared a common physical format. As Andrew Nash points out, "an essential part of the rationale of series publishing is uniformity in physical appearance." Janet Friskney also suggests that the "use of common title and cover design is not simply cost-effective; it creates brand-name recognition, and at its most successful encourages consumers to collect multiple volumes. ${ }^{10}$ Like other uniform series of reprints, the Modern Library used the same typography, binding and endpapers for all its publications. When Bennett Cerf and Donald Klopfer bought the 
Modern Library from Horace Liveright in 1925, they commissioned graphic designer Lucian Bernhard and typographer Elmer Adler to give a more modern look to the series. Bernhard designed the endpapers as well as the colophon, a long-legged running torchbearer. Adler, whose company Pynson Printers specialized in limited editions, created a distinguished title page. Like all Modern Library books issued in 1928, Portrait of the Artist and Fourteen Great Detective Stories had the same spine design and flexible leatherette binding. Even dust jackets had a similar appearance (Figure 1).

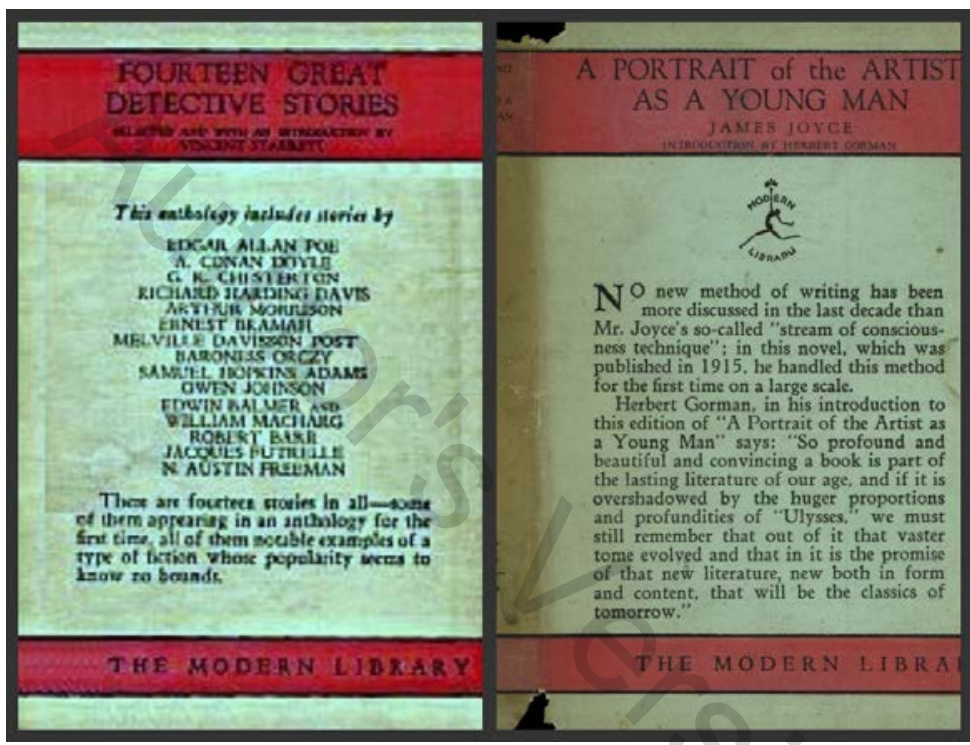

Figure 1: 1928 dust jackets of Fourteen Great Detective Stories and A Portrait of the Artist as a Young Man

Not only did the two books share a similar physical format, they were displayed in the same way. Indeed, Fourteen Great Detective Stories was number 144 in the series, and Portrait of the Artist, number 145. As booksellers generally arranged Modern Library books by numbers on a special display rack (Figure 2), most consumers would have encountered the two books simultaneously. The fact that the Modern Library was displayed as a coherent collection conveyed cultural prestige. In his essay on the Leonard Bast's Library, Robert Fraser observes that publishers of uniform series "half-snobbishly invit[ed] their patrons to lay hold of cultural capital in a palpable form: in effect to adopt a miniature of the walk-in gentleman's libraries." ${ }^{11}$ The immensely 
successful Everyman's Library also capitalized on the democratic idea that "everyman" could build up a great gentleman's library. As Kevin Dettmar notes, “during the modernist period, an important cultural power vacuum opened up, in which the cultural prestige (what Bourdieu dubs 'distinction') traditionally accorded to, variously, literacy, books, private libraries, and literary learning, recedes in the face of a greatly democratized print culture." ${ }^{12}$ Like its competitor Everyman's Library, the Modern Library participated in this democratized print culture by presenting itself as distinguished and affordable. Since Modern Library books were sold at only 95 cents per volume, even students and clerks could afford to buy multiple "classics" and display them as a library.

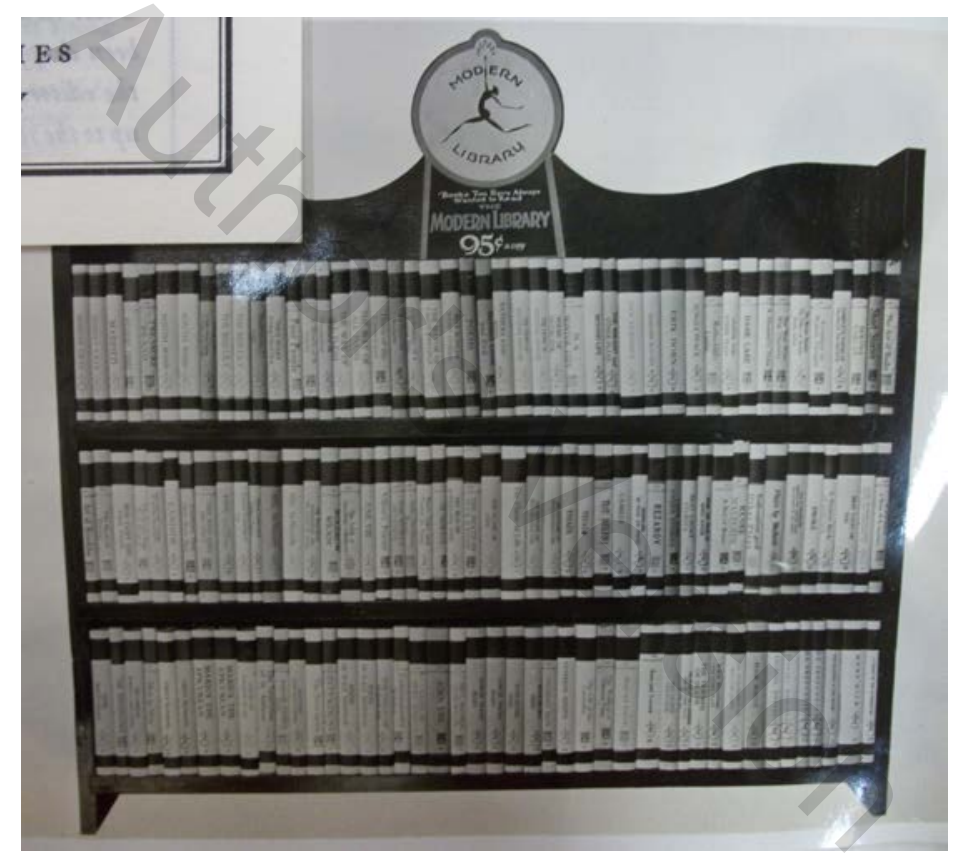

Figure 2: Modern Library Display Rack, 1927, box 36, Cerf Papers, Columbia Rare Book and Manuscript Library

Unlike other publisher's series, the Modern Library expanded the term "classic" to include recent works of fiction and non-fiction. As Jonathan Rose and Mary Hammond have shown, the "classic" was never a fixed category: certain texts were included in uniform series of classics because they were cheap to produce and sold in large quantities, not because they were "greater" than others. ${ }^{13}$ The whole economy of the publisher's series depended on copyright laws. For example, Everyman's Library was created at the time when the copyrights of the Great Victorians 
were expiring (Rose 133). In contrast, the Modern Library was the first publisher's series to include large numbers of copyrighted texts, thus offering a unique product to the American market.

This expansion of the term "classic" did not endanger the balance between distinction and cheapness typical of all uniform series. As Hammond puts it, “a book is a 'classic' almost wholly because a particular publisher says it is" (94). The Modern Library used its "power to consecrate" to present Portrait of the Artist and Fourteen Great Detective Stories as classics that would transform the reader into a sophisticated connoisseur. ${ }^{14}$ The equation of the classic with distinction was maintained because the Modern Library defined cultural sophistication as the ability to read a wide range of books - thus reaching outside the narrow specialization characteristic of the professionalmanagerial class. A prospectus for the Modern Library magazine (a project aborted due to the Depression) thus described its audience as "the civilized minority": "It consists of people vitally interested in their own field who know what they are talking about, and want to know what people of their own kind are thinking in other fields." 15 Modern Library readers were thus presented as open-minded people who enjoyed reading all sorts of texts in a distinguished physical format.

The uniformity of the Modern library was conveyed by the format and the display of the books, but also by advertisements. Indeed, adverting campaigns for the Modern Library generally focused on the brand itself, rather than on individual titles. The objective was to convince consumers that all Modern Library books were worth reading. As one advertisement in the American Mercury put it, "the 95 cent price is made possible by tremendous volume production that and the fact that there are no failures, no doubtful quantities in the Modern Library. Every book chosen has already been endorsed by the American public as a great book worthy to endure. Every author represented has already won his place among the great men of literature." ${ }^{16}$ Modern Library editors eagerly embraced the logic of large-scale production and democratization. They combined this rhetoric with an appeal to good taste, claiming to publish the world's best books for an audience of modern readers. 
In September 1928, the Modern Library advertised a list of its "fifty best sellers" (out of a total of 150 titles) in Publishers' Weekly. ${ }^{17}$ The advertisement encouraged booksellers to have "a good supply of these books for Christmas." Fourteen Great Detective Stories and A Portrait of the Artist as a Young Man were listed in this order, after Jude the Obscure and before The Emperor Jones and the Straw (Figure 3). There are no complete sales records in the Random House archives, but one document gives the figures for January-June 1928. Fourteen Great Detective Stories sold 4,116 copies and Portrait of the Artist, 3,791 copies during this period. (As both books were released in March, these figures correspond to the first four months following publication.) Despite the constant reference to "bestsellers" in advertisements, the Modern Library did not reach the mass market. Yet, the series significantly increased the market for Joyce's novel, a title that had previously been available in a $\$ 1.50$ edition published by the small press of B. W. Huebsch. Moreover, Portrait of the Artist sold three times more copies than Best Ghost Stories did in six months. ${ }^{18}$ Modernist and "difficult" novels could thus be more commercially successful than genre fiction. ${ }^{19}$ 


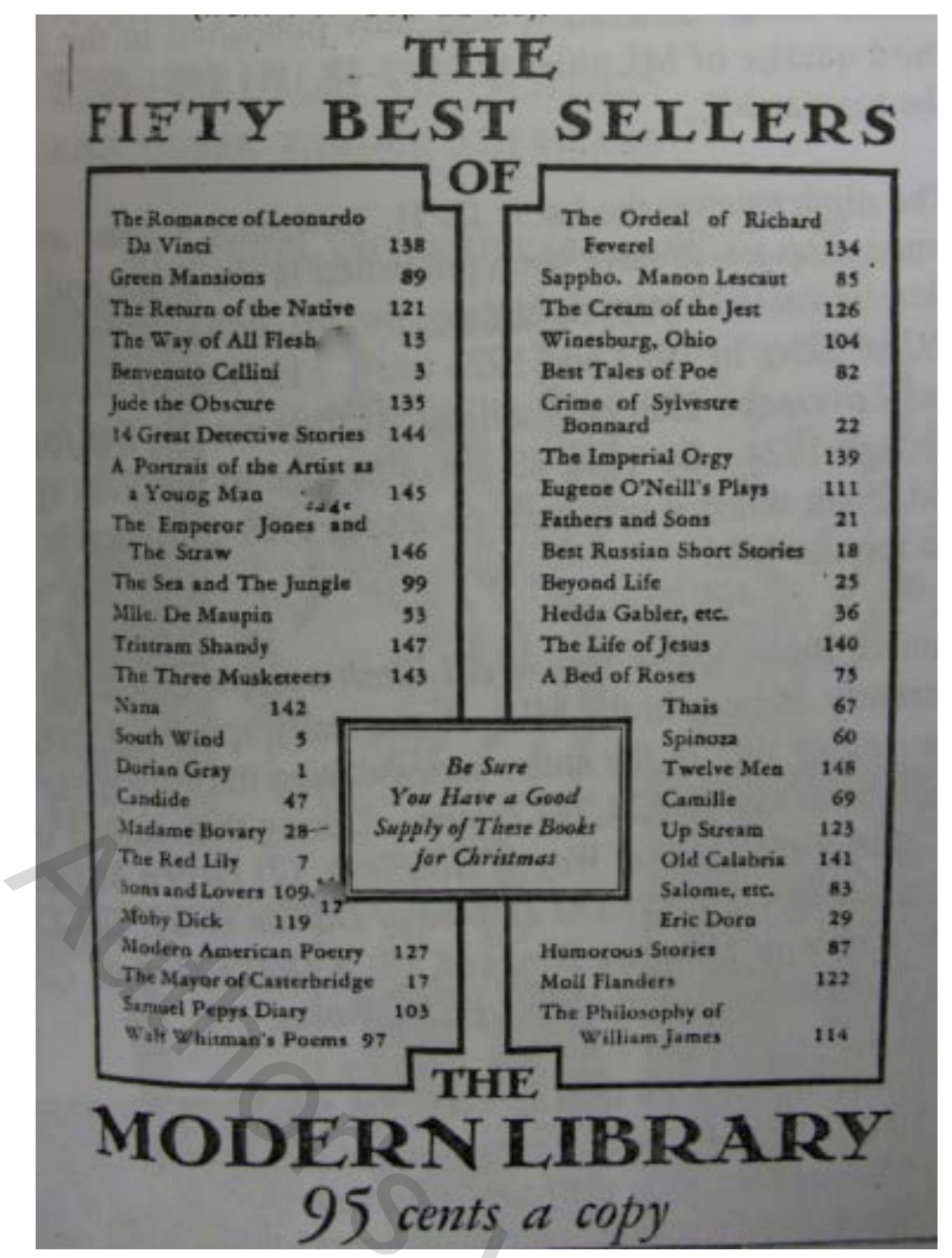

Figure 3: Advertisement for the Modern Library, Publishers' Weekly 114 (22 Sept. 1928), 1035

The term "bestseller," which suggests a short cycle during which the product is manufactured, advertised, sold to the mass market and discarded, was in fact ill-suited to describe Modern Library books. "Longseller" would be more accurate, as many of these books stayed for decades in the series. Fourteen Great Detective Stories and Portrait of the Artist remained in the Modern Library for forty-two years and twenty-eight years respectively. Portrait of the Artist started with a first printing of 8,000 in 1928 , and by 1950 the total number printed had reached $99,000 .{ }^{20}$ Sales increased after the war, at the time when modernism was being institutionalized in universities: between November 1951 and October 1952, nearly 6,100 copies were sold. ${ }^{21}$ Portrait of the Artist remained in the Modern Library until 1956, when the copyright holder Viking decided to issue its own cheap edition. From 1928 to 1956, the Modern Library probably sold more than 
100,000 copies of Portrait of the Artist. Unlike the "slick" magazines and the book clubs, the Modern Library did not reach the masses - but it created a significantly larger market for Portrait of the Artist and other titles that had previously been published in little magazines and small presses.

Although the term "bestseller" was hardly appropriate, the Modern Library used it as a marketing tool to emphasize the attractiveness of its list, rather than a strict indicator of its sales figures. ${ }^{22}$ Advertisements suggested that Modern Library editions were not dusty old classics, but desirable books that had stood the test of time. ${ }^{23}$ According to one ad in the New York Times, "the titles chosen for publication are the best sellers of yesterday and today. . . The Modern Library, by publishing an attractive, inexpensive edition of these books, places the world's best literature within reach of the humblest book-buyer." 24 The Modern Library did not distinguish between books such as Portrait of the Artist and Fourteen Great Detective Stories precisely because its marketing strategy relied on presenting all Modern Library books as bestsellers, even if some sold less than others.

It is tempting to see the anthology of detective tales as a potboiler, a necessary addition to help less profitable titles in the list. If that were the case, Modern Library editors would have gone to great length to avoid the risk of "brand dilution," defined as the "weakening of positive brand associations or strengthening/ addition of negative brand associations." 25 For instance, the Modern Library could have advertised popular titles in mass-market publications and "difficult" novels in little magazines. In fact, Joyce's text and the detective anthology were advertised in the same literary publications such as the New York Times Book Review and New Republic (Figure 4). Far from belonging to different categories, Portrait of the Artist and the detective stories were part of the "150 Great Modern Books.",26 


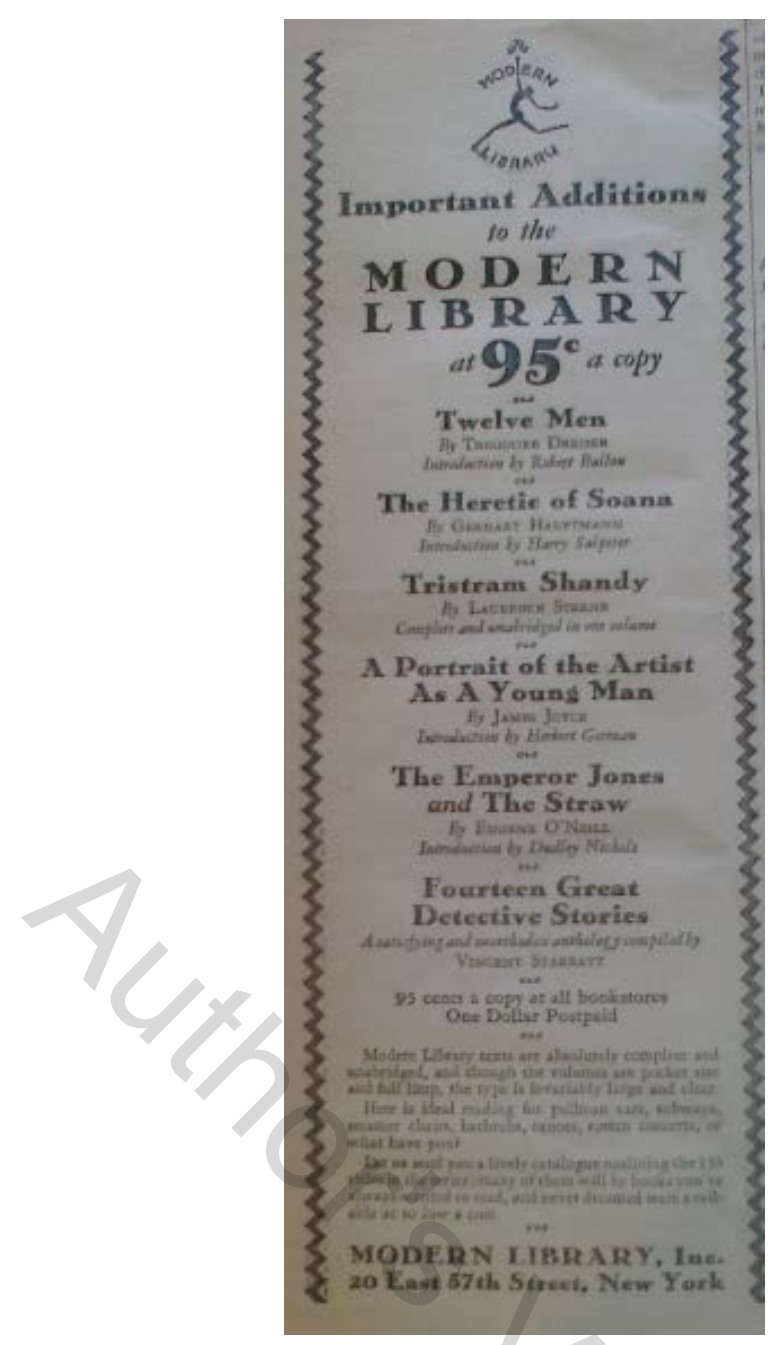

Figure 4: Advertisement for the Modern Library, New Republic 56 (15 Aug. 1928), 340

The blurbs and introductions of Fourteen Great Detective Stories and Portrait of the Artist presented both books as modern classics that could appeal to a large audience. In the case of Joyce's novel, the blurb on the dust jacket insisted not only on its stylistic originality but also on its popularity: "No new method of writing has been more discussed in the last decade than Mr Joyce's so-called 'stream of consciousness technique." Those who did not want to be left out of this ongoing discussion had better read Portrait of the Artist, beginning with Herbert Gorman's introduction (from which the blurb was extracted). ${ }^{27}$ Far from presenting Joyce's novel as difficult, Gorman described it as a page-turner: "it is the mind of Stephen Dedalus that enchants and absorbs us and it is our consciousness of the authenticity of this figure that makes us so reluctant to lay the 
book down. ${ }^{, 28}$ Portrait of the Artist was thus presented as an attractive novel that everybody could read. $^{29}$

For Gorman, Joyce's novel offered "the promise of that new literature, new both in form and content, that will be the classics of tomorrow" (xii) - a claim that also appeared on the dust jacket. The fact that the Modern Library had chosen Portrait of the Artist for its series gave the novel a new authority as a modern classic, as a text that was both timely and timeless. However, Gorman stated that Joyce's true masterpiece was not Portrait of the Artist but Ulysses, a novel in which the stream-of-consciousness method had been "carried to its eventual goal" (vii). In 1928, Ulysses was still banned in the United States on charges of obscenity. One reviewer also described Portrait of the Artist as "slightly pornographic." 30 The choice to include Joyce in the Modern Library fitted well with its image as a daring collection that attempted to educate readers about current and controversial literary trends.

The dust jacket of Fourteen Great Detective Stories similarly conveyed the impression that the book was a classic that participated in modernity. These stories had been chosen for their literary quality, as the word "great" implied, but there were also fun to read. The blurb on the dust jacket claimed that "all" the fourteen detective stories were "notable examples of a type of fiction whose popularity seems to know no bounds." The Modern Library edition included five stories that also appeared in Crime and Detection (1926), an anthology published in the Oxford World's Classics series: Edgar Allan Poe's “The Purloined Letter,” Arthur Conan Doyle's “The Red-Headed League,” Arthur Morrison's “The Stanway Cameo Mystery,” R. Austin Freeman's “The Case of Oscar Brodski,” and Ernest Bramah's “The Tragedy of Brookbend Cottage.” Apart from Poe, all the authors anthologized in the Oxford World's Classics edition were British. Unlike its competitor, the Modern Library targeted the US market with a balanced list of seven British and seven American authors. ${ }^{31}$ By the end of the 1920 s, detective fiction had become a popular and respected genre, published in uniform series alongside more traditional "classics." 
The year 1928 certainly saw a boom in the demand for detective tales, fuelled by innovations such as the new book clubs. Indeed, the creation of the Book-of-the-Month Club had been followed by a wave of other clubs, including the Detective Story Club and the Crime Club. Doubleday Doran launched the latter in March 1928, the same month the Modern Library anthology of detective stories was released. ${ }^{32}$ The Crime Club's logo, which showed a Cubist-inspired figure with a gun, decidedly anchored crime fiction in modernity (Figure 5). Although the essayist Simeon Strunsky maintained that it was "pleasant . . . to find how free the average detective novel is from the disintegrating forces that threaten society and constitute modern unrest, ${ }^{, 33}$ the detective genre did in fact participate in this unrest. One advertisement for the Crime Club promised monthly thrills to readers: "Your pulse quickens as you take off the wrapper; your excitement grows as you look at the contents. ${ }^{\prime 34}$ This over-stimulation of the senses characterized the modern experience, as the sociologist Georg Simmel had noted. ${ }^{35}$ It is hardly surprising that detective fiction, a genre that created intense nervous stimulation, would have reached a peak of popularity after the First World War. $^{36}$

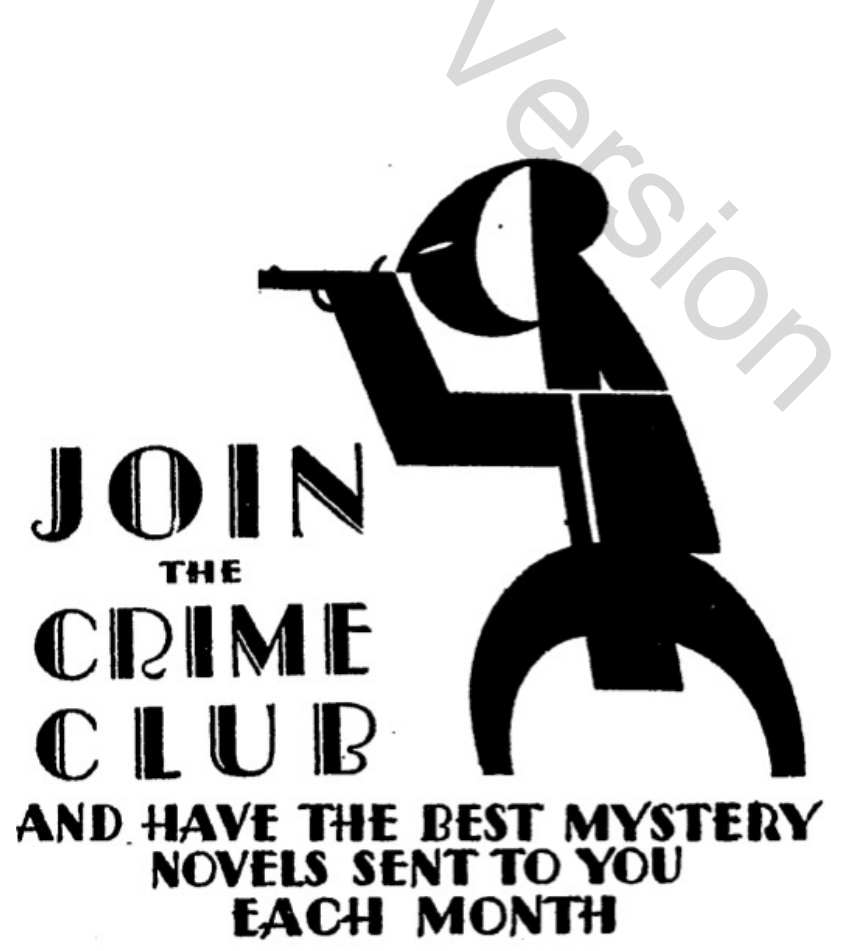

Figure 5: Advertisement for the Crime Club, New York Times Book Review (29 April 1928), 19 
Even methods for advertising detective stories were decidedly modern. One article in the English Journal pointed to the "unprecedented amounts" spent by book publishers on advertising detective fiction: "a book entitled Murder was promoted through the medium of an airplane flying over New York at night with the illuminated exhortation to 'Read Murder." "37 Onlookers must have been stuck by this spectacle - which reminds us of the skywriting airplane in Mrs Dalloway. Like literary modernism, the detective genre participated in modernity. ${ }^{38}$

While detective stories relied on a very modern appetite for nervous excitement, their setting and plot were far from the reality of crime in America. Hard-boiled writers such as Raymond Chandler would later criticize the classic detective stories published "in the big shiny magazines, handsomely illustrated, and paying due deference to virginal love and the right kind of luxury goods. ${ }^{, 39}$ But the elitism of detective fiction was part of its appeal. While pulp magazines published hard-boiled fiction for an imagined audience of working-class readers, ${ }^{40}$ periodicals such as Scribner's Magazine marketed classic detective tales for a middle-class audience.

By the late $1920 \mathrm{~s}$, detective fiction had become sufficiently respectable to attract a distinguished readership. Even professors of English literature took an interest in this genre. "Today we have not only a detective and mystery 'literature' but we are beginning to have a literature about the detective and mystery novel," wrote Arthur McKeogh and William Brown Meloney in the English Journal (625). They argued that “all fiction is 'literature of escape,' from James Joyce to E. Philips Oppenheim" (626). Modern Library editors would certainly have agreed with this refusal to create boundaries between genres. For McKeogh and Meloney, detective fiction had travelled a long way from its lowbrow image: "with the increased interest in crime literature, more and more sophisticated persons began reading them and the quality and product was raised to meet this new demand" (630). Likewise, Vincent Starrett's introduction to Fourteen Great Detective Stories insisted on this prestigious readership: "When their yarns are good, Presidents and Princes rise in meeting to advertise their delights in them." ${ }^{41}$ Even the title of the introduction, "Of Detective 
Literature," pointed to the new prestige of this genre. In the late 1920s, then, detective fiction was increasingly accepted as an important part of the emerging canon of modern literature.

The advertisements, blurbs, introductions and other paratextual elements presented Fourteen Great Detective Stories and Portrait of the Artist as quality books that appealed to the modern mind. The idea that a classic could also be a page-turner was central to the Modern Library's marketing strategy. How did reviewers react to this strategy? Did they show any surprise at the side-by-side publication of two books that we now consider radically different?

\section{II) Reviewing}

Joyce was already a well-known writer when Dubliners and Portrait of the Artist were added to the Modern Library. ${ }^{42}$ As Karen Leick has shown, "it would have been difficult for any literate American to remain unaware of modernists like Joyce and Stein in the 1920s, since their publications in little magazines were discussed so frequently in daily newspapers and in popular magazines. ${ }^{\prime 43}$ Yet, few scholars have noted that the mainstream press started reviewing Joyce's texts in the 1910s, well before the publication of Ulysses. In 1917, the Chicago Daily Tribune observed that "no less a personage than that prime minister of literary England, H. G. Wells, has declared that James Joyce's A Portrait of the Artist as a Young Man is the discovery of the year."44 Joyce's novel was even reviewed in mass-market magazines with circulation in the hundreds of thousands. Munsey's Magazine, a conservative weekly, thus published a 1917 review on the "Bad Taste of a New Irish Novelist." disgusting material," but also recognized that "Mr Joyce has written with remarkable power a remarkable book." Instead of an unintelligible highbrow text, Portrait of the Artist was described as a realistic novel, with pages "so true to life and character that, were these all, the tale would be a contribution to the real literature of the time." For Munsey's, then, Portrait of the Artist was an important novel by a writer who had not yet overcome his adolescent fascination for pornography. 
The controversy over Ulysses quickly transformed Joyce into a household name. As the Los Angeles Times stated in 1922, “many are discussing James Joyce's Ulysses, but few are reading it, as the book was published in Paris by subscription, in a limited edition. Meantime, due to its fame, there has been a revival of the demand for Joyce's other books here and in England." ${ }^{46}$ The New York Times also pointed to the "new interest in the earlier writings of James Joyce," relaying Huebsch's report on the "heavy sales of A Portrait of the Artist as a Young Man, Dubliners, and Exiles. ${ }^{, 47}$ Despite the relatively high price of the Huebsch edition, Portrait of the Artist appealed to a large audience. One reader wrote to the Los Angeles Times in 1923 to praise Portrait of the Artist, "a story which has been widely read and is recognized as one of the superior literary merit." 48 A few months later, the same newspaper published an article entitled "James Joyce, the New Irish Immortal" in its Illustrated Magazine section. ${ }^{49}$ Joyce was a celebrity in America well before Random House's publication of Ulysses in 1934.

At the time when the Modern Library released Portrait of the Artist and Starrett's anthology of detective stories, reviewers did not view the cultural landscape in terms of rigid hierarchies. Daily newspapers often mentioned the publication of Joyce's novel and Fourteen Great Detective Stories without distinguishing between the two texts, since both had appeared the same month in the same series of reprints. In a review entitled "Detective Tales and James Joyce," the Hartford Courant insisted that both texts belonged to modern literature. ${ }^{50}$ Joyce's novel was strongly praised: “A Portrait of the Artist marks the height of Mr Joyce's achievement as writer, and the editors of the Modern Library have done well in including it in the series." The reviewer stated that "in spite of the hue-and-cry roused by Ulysses, it is probable that Mr James Joyce's ultimate fame will rest on The Dubliners, and A Portrait of the Artist as a Young Man." As the publisher of the two latter texts, the Modern Library was presented as a series of modern masterpieces. As Figure 6 shows, reviews also appeared in newspapers far from the literary centres of the East coast (as well as in Canada, Australia and even Cuba). ${ }^{51}$ The Journal of Sioux City, Iowa, published an article on "Detective Tales and an Early 'James Joyce,", presented as "two attractive additions to the 
series." 52 The Spokane Daily Chronicle also published a review on the "two interesting volumes" included in the Modern Library: "One is James Joyce's famous novel, A Portrait of the Artist as a Young Man ... the other is a collection of Fourteen Great Detective Stories selected by Vincent Starrett." That a newspaper based in Spokane, Washington - far from the literary centers of the East Coast - could present Portrait of the Artist as a "famous novel" tells us a lot about Joyce's celebrity in the 1920s. The two Modern Library books were described as equally pleasant to read. Gorman's "entertaining and instructive" introduction would reassure those readers who might have feared Joyce's reputation for stylistic experimentation. The fourteen detective stories were also "thoroughly enjoyable," wrote the reviewer after discussing the difficulty to "agree on the greatest stories of the kind in English." 53 The response of the daily press to the Modern Library's new additions shows that literary modernism and mainstream culture were increasingly intertwined in the late 1920s.

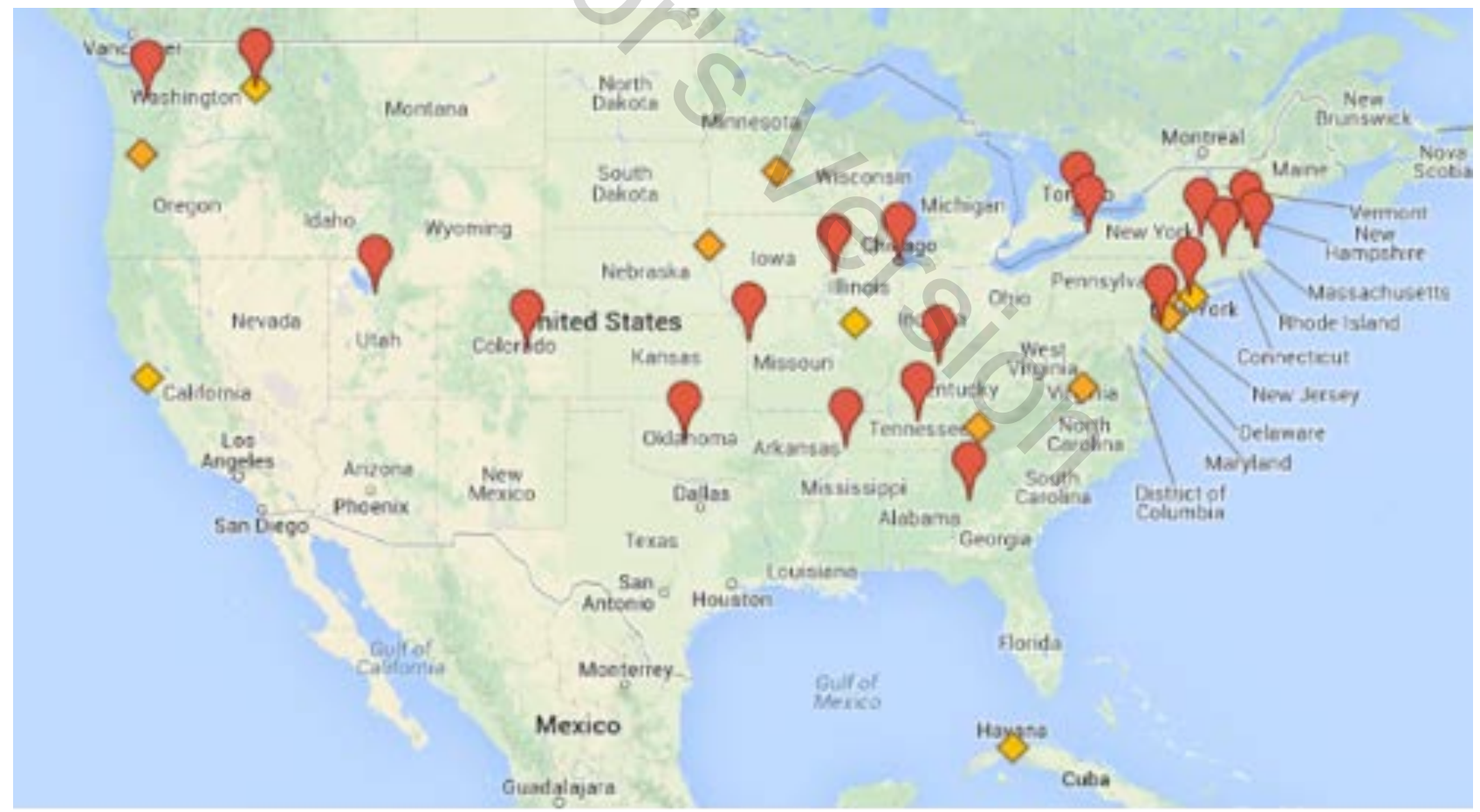

Figure 6: Reviews, Modern Library ed. of Portrait of the Artist and Fourteen Great Detective Stories (Balloon shape: Portrait alone; diamond shape: Portrait and Detective Stories). ${ }^{54}$

Even a literary magazine such as the Dial eagerly engaged with "popular" culture. Interestingly, it was not the Modern Library edition of Portrait of the Artist, but Fourteen Great 
Detective Stories that attracted the Dial's interest. In a long review, Gilbert Seldes praised Starrett's choice of detective stories: "all the stories included are good and half of them certainly rank with another half dozen or so, as the best of the lot." ${ }^{55}$ Anticipating later critics, ${ }^{56}$ Seldes attempted to apply psychoanalytic analysis to explain the "satisfaction" of reading detective stories: "I do not know whether psychoanalysts have gone to the bottom of the almost universal passion for police romances. Probably it is due to a variety of suppressed desires - to commit murder and to prevent murder, to live dangerously and to love policemen" (521). Seldes's reference to psychoanalysis exemplifies the modernity of the detective genre. The creators of the Modern Library, Albert Boni and Horace Liveright, largely contributed to the popularization of psychoanalysis in America. They published a number of Freud's early books and in 1924, Liveright added An Outline of Psychoanalysis to the Modern Library catalogue. Like the Modern Library editors, Seldes did not hesitate to mix literary modernism with detective stories.

Seldes was the editor of the Dial from 1920 to 1924, an exciting period in the history of the magazine. The first American printing of T. S. Eliot's The Waste Land appeared in the November 1922 issue. That year, Seldes wrote an enthusiastic review of Joyce's Ulysses for The Nation, “one of the (if not the very) first notices to appear in the United States." ${ }^{, 57}$ As Michael Kammen argues, Seldes believed that "high culture and popular culture could beneficially converge" (10). By 1927, he had started reviewing detective fiction. ${ }^{58} \mathrm{He}$ even wrote his own detective stories, published under the penname of Foster Johns. ${ }^{59}$ Seldes's review of Fourteen Great Detective Stories in The Dial was followed by brief reviews of newly released books, including Van Dine's The Greene Murder Case and Yvor Winters's The Bare Hills. Winters has since joined the canon of poets associated with New Criticism, while Van Dine has been dismissed as a second-rate detective writer. The fact that The Dial enthusiastically reviewed the works of these two writers (along with Fourteen Great Detective Stories) shows the flexibility of cultural categories in the interwar period.

\section{III) Dividing}


The post-war era saw the widening of the gap between the "high" and the "popular." For the New York Intellectuals (and their allies, the New Critics), ${ }^{60}$ detective fiction exemplified the vices of mass culture. The post-war anxiety of contamination was not simply a reiteration of earlier fears of "vulgar" culture. The New York Intellectuals had come of age at a time of intense political tensions, and had grown disillusioned with Marxism. The examples of Stalinist Russia and Nazi Germany seemed to highlight the disastrous consequences of mass culture. As Hugh Wilford points out, both the theorists of the Frankfurt School and the New York Intellectuals "had an apocalyptic vision of the future, one in which the traumatised masses erupted in directionless and barbaric violence." ${ }^{61}$ Serge Guilbaut also notes that "by fighting through art against mass culture, artists [and critics] enjoyed the illusion of actively fighting against repugnant regimes, using the weapons of the elite." 62

The emergence of a rigid separation of the "high" and the "low" finds its origins in the political turmoil of the 1930 s, but also in economical changes. "As they began to fear the prospect of being reduced to the same level as the millions of other knowledge workers," the new generation of intellectuals insisted on isolating an elite culture from the mainstream. ${ }^{63}$ The post-war was a period of intense criticism of corporate conformity, with books such as C. Wright Mills's White Collar lamenting the "decline of the free entrepreneur and the rise of the dependent employee on the American scene." 64 The only way to preserve the values traditionally associated with "art" originality, independence, and creativity - seemed to create walls between the elite and the masses. Although the New York Intellectuals often criticized academia and other institutions that threatened an independent life of the mind, modernism came to be constructed as a difficult movement studied by professionals in university departments. ${ }^{65}$

In this intellectual context, it is hardly surprising that a diverse series such as the Modern Library would have come under attack. In the 1940s, for instance, many intellectuals criticized the decision to drop Stendhal's The Charterhouse of Parma from the Modern Library list. ${ }^{66}$ Harry 
Levin caustically wrote that The Charterhouse had been dropped because publishers "thought that they were unable to sell it as numerously as such great works as Life with Father and Rebecca." ${ }^{, 7}$ Levin was not the only intellectual to look down on Daphne du Maurier's Rebecca, the leading bestseller in 1938 and 1939. In a letter to the Christian Science Monitor, the British writer V. S. Pritchett described the book as a mediocre "Victorian thriller." ${ }^{68}$ When Rebecca was reprinted in the Modern Library in 1943, it was marketed as a thriller, with a dust jacket designed by E. M. Kauffer that featured a macabre housekeeper on a black background. While Pritchett and Levin saw Rebecca as a mass-culture product, the Modern Library presented it as classic that deserved its place among the "world's best books." The series was increasingly seen as a scandalous enterprise that failed to cordon off "good" literature from thrillers and other debased genres. In an essay entitled "Will the Commercialization of Publishing Destroy Good Writing?," James T. Farrell thus noted that the Modern Library "is sometimes watered down by such books as the works of Dashiell Hammett which are, at most, a little bit less than classics of the ages." 69 The verb "water down" suggested a failure to preserve the purity of high culture from a debased popular culture.

In the writings of post-war critics, modernism was often opposed to the crass commercialism of detective fiction. For example, Edmund Wilson's 1945 essay, "Who Cares Who Killed Roger Ackroyd?," was structured by oppositions between "Literature” (with a capital L) and "rubbish." ${ }^{70}$ Wilson praised the story-telling skills of modern writers: "even Proust and Joyce and Virginia Woolf do certainly have stories to tell, and they have organized their books with an intensity which has been relatively rare in the novel and which, to my mind, more than makes up for the occasional viscosity of their narrative" (152). In contrast to the difficult but rewarding reading of modernist texts, the consumption of detective stories was, in Wilson's terms, “degrading to the intellect" (153). Wilson compared the reading of detective fiction to a shameful addiction: "detective-story readers feel guilty, they are habitually on the defensive, and all their talk about 'well-written' mysteries is simply an excuse for their vice, like the reasons that the alcoholic can always produce for a drink" (152). ${ }^{71}$ 
If detective fiction was really dangerous and degrading, why did modernist writers such as T. S. Eliot and André Gide talk about their admiration for Wilkie Collins or Dashiell Hammett? ${ }^{72}$ Both Edmund Wilson and Dwight Macdonald agreed that Gide's endorsement of Hammett was socially disastrous. For Wilson, "the portentously invoked examples of Woodrow Wilson and André Gide" "bullied" readers into consuming detective fiction (153). In his 1953 essay, "A Theory of Mass Culture," Macdonald similarly condemned Gide, who was "foolish enough to admire" the "noxious" style inaugurated by Hammett. ${ }^{73}$ These metaphors of disease and corruption highlighted the risk of contamination between the "high" and the "low," between good literature and "rubbish." 74 What was at stake was not so much the mediocrity of the detective genre, but rather the blurring of the boundaries between literary modernism and crime fiction characteristic of the interwar period. ${ }^{75}$ In the $1940 \mathrm{~s}$ and $1950 \mathrm{~s}$, at a time when the responsibility of the writer was violently debated, intellectuals who defined themselves as "serious" could no longer endorse supposedly harmful popular genres. ${ }^{76}$

But why did an iron curtain descend across the arts right after the Second World War? Why did intellectuals suddenly seem anxious to draw a line between modernist writings and detective stories? Jay Satterfield notes that the huge popularity of Pocket Books and other paperback series triggered attacks against the commercialization of publishing: "because of the low profit margin per unit, paperback reprint lines and most other cheap series demanded high-volume sales. Only books with significant market appeal would be reprinted" (145). In fact, the Modern Library had little in common with mass-market paperbacks. At 95 cents, Modern Library books were nearly four times more expensive than early paperback editions (Pocket Books sold for 25 cents in 1939, for example). Second, the Modern Library was distributed in bookstores rather than newsstands, and reached a much smaller market. For instance, the Signet edition of Faulkner's Sanctuary sold 1,103,424 copies between April 1947 and May 1951 (an average of c. 276,000 per year). The Modern Library edition sold only 4,844 copies between November 1951 and October $1952 .{ }^{77}$ Third, unlike paperbacks that were meant to be thrown away after reading, Modern Library editions had a 
stylish appearance and durable hardcovers. From 1939 to 1962, Modern Library bindings were made of linen cloth over stiff cardboard. Finally, the dust jackets of Modern Library books were much more restrained than the lurid covers of many paperback editions.

Critics failed to distinguish between the Modern Library and paperback series because both published a diverse range of titles without dividing the "high" from the "low." As David Earle has shown, literary modernism often appeared in "early fiction and reprint magazines, interwar pulp magazines, and popular paperbacks," a genealogy that has been largely neglected because of "the academic prejudice of form." ${ }^{, 78}$ In 1948, for example, the New American Library reprinted Thomas B. Dewey's As Good as Dead (number 663 in the series), Joyce's Portrait of the Artist (number 664) and Mickey Spillane's first novel, I, the Jury (number 699) under its Signet imprint. ${ }^{79}$ Dewey and Spillane belonged to the same hard-boiled school that Macdonald and other post-war critics despised. Spillane was often singled out as the representative of the worst kind of detective fiction full of violence and sex, and written only for monetary gain. ${ }^{80}$ This unflattering reputation stemmed not only from Spillane's unheard-of commercial success, but also from the racy covers of the paperback editions of his novels. The 1948 Signet edition of $I$, the Jury thus pictured a blonde woman undressing in front of the detective. Similarly, the cover of Portrait of the Artist showed a young female exposed to the male gaze (Figure 7). ${ }^{81}$ The New American Library made no distinction between Spillane and Joyce: I, the Jury and Portrait of the Artist were both sold to the mass-market with sexy covers and sensational blurbs ("Passion, Crime, and Suspense;" "The Popular Masterpiece by the Author of Ulysses"). ${ }^{82}$ 


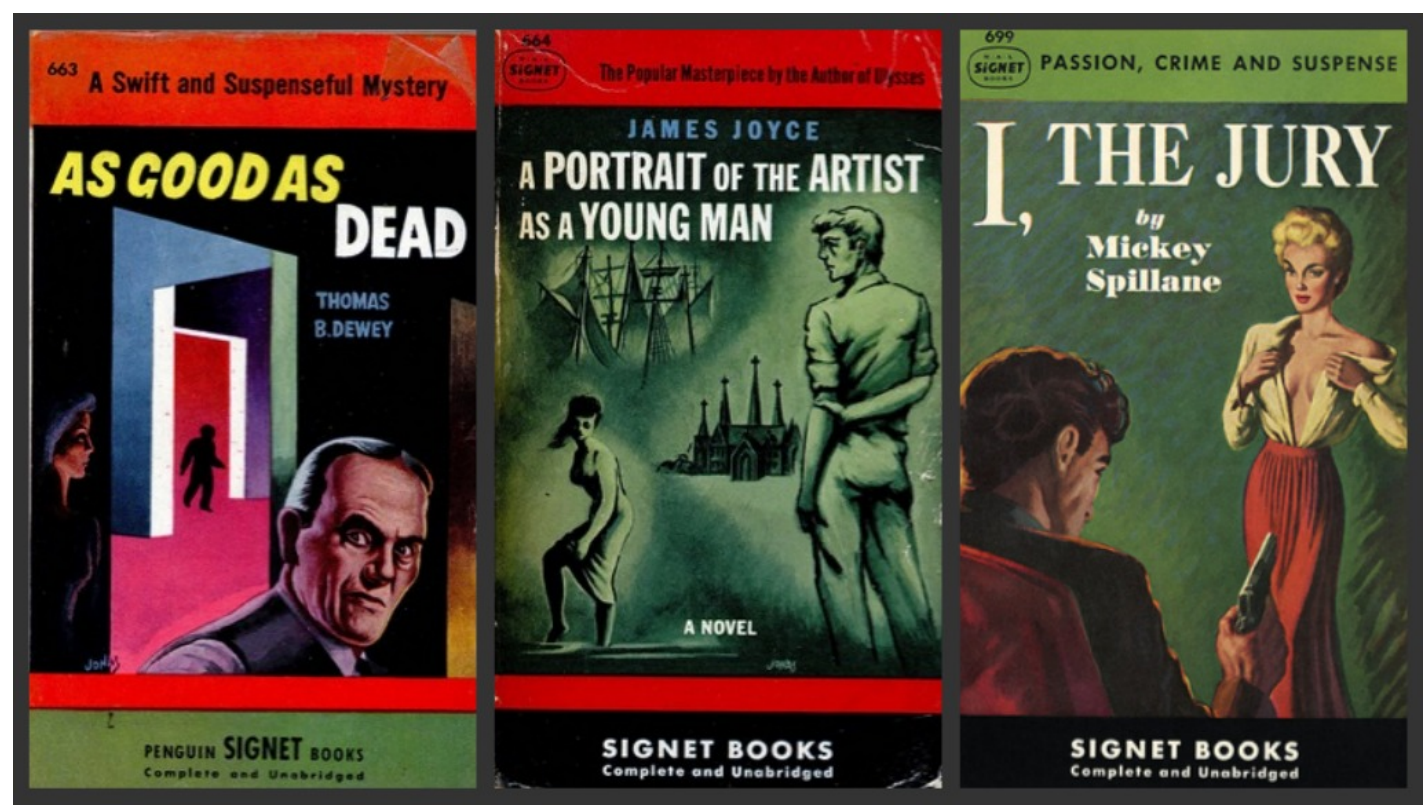

Figure 7: Covers, New American Library, Signet imprint, 1948. Illustrations by Robert Jonas (left and center) and Lu Kimmel (right)

Both the New American Library and the Modern Library positioned themselves as quality series that published a diverse selection of titles. ${ }^{83}$ In 1953, the same year when Macdonald published his essay on mass culture, a major department store in Chicago thus announced the arrival of a "complete stock" of Modern Library books. "How Many of the Best of the World's 'Best' Books Have You Read?' asked the advertisement, above a list of over 200 Modern Library books listed by their number. Fourteen Great Detective Stories and Portrait of the Artist were still in print, and appeared in this order on the advertisement. ${ }^{84}$

Macdonald strongly criticized this kind of "homogenized culture." In "A theory of Mass Culture," he wrote:

Like nineteenth-century capitalism, Mass Culture is a dynamic, revolutionary force, breaking down the old barriers of class, tradition, taste, and dissolving all cultural distinctions. It mixes and scrambles everything together, producing what might be called homogenized culture, after another American achievement, the homogenization process that distributes the globules of cream evenly throughout the milk instead of allowing them to float separately on top. It thus destroys all values, since value judgments imply discrimination. Mass Culture is very, very democratic: it absolutely refuses to discriminate against, or between, anything or anybody (62, my emphasis). 
For Macdonald, "homogenized" institutions reduced culture to its lowest-level common denominator. He gave the example of the magazine Life, which typically featured "nine color pages of Renoirs plus a memoir by his son, followed by a full-page picture of a roller-skating horse" (62). Drawing on Marx's analysis of the destructive power of capitalism, Macdonald condemned the disappearance of cultural categories and value judgments. No art form was sacred any more, and all that was solid had melted into air.

The Modern Library, which had exemplified the democratized print culture of the interwar period, was now condemned for being too democratic. For post-war critics, institutions such as the Modern Library and the paperback series had destroyed the romantic aspiration to cultural greatness. By mixing Joyce with detective writers, these institutions sent out the message that no work was greater than another. In "Masterpieces as Cartoons," an essay published in Partisan Review, Delmore Schwartz wrote: "even when a reader goes from James M. Cain to William Faulkner and James Joyce because they are available in pocket book form for twenty-five cents, most readers who come to Faulkner and Joyce by means of pocket books do not know the difference between James M. Cain and James Joyce or Dashiell Hammett and William Faulkner; and some of the time they do not remember the names of the authors, no matter how many of their works they read. ${ }^{, 85}$ For Schwartz, the failure to distinguish between great modernist writers and hard-boiled hacks like Cain and Hammett exemplified the disappearance of taste levels, and the triumph of a relativist mass culture.

The intransigence of post-war critics towards detective fiction would have been alien to James Joyce. Far from decrying the reading of detective tales as a shameful addiction, Joyce incorporated references to Sherlock Holmes in Ulysses and Finnegans Wake. ${ }^{86}$ As R. Brandon Kershner has argued, "Ulysses as a whole shares much with the detective story. It demands of both its characters and its readers scrupulous attention to detail and active interpretation., ${ }^{, 87}$ Joyce's earlier works also present similarities with detective fiction. Suzanne Ferguson has thus noted that 
"the emphasis on discovery" is central in both the Holmes stories and Dubliners: "The "sudden spiritual manifestation' of an epiphany illuminates the relation of the inner life to formerly incomprehensible outward signs; the discovery of the crime reveals motives, means, and identities out of the muddle of clues." ${ }^{, 88}$ The same could be said of the epiphanies in A Portrait of the Artist as a Young Man. In the bird girl episode, Stephen's “outburst of profane joy" is described in terms of sudden revelation $(P 171)$, a revelation that reminds us of the eureka moment of the sleuth who has just solved a crime. At the end of Conan Doyle's "The Red-Headed League," a tale included in Fourteen Great Detective Stories, Holmes explains to Dr Watson that his detective work helps him "escape from the commonplaces of existence." ${ }^{89}$ Both Holmes and Stephen attempt to make sense of modern life, to find meaning in the absence of clear purpose and direction. These similarities between detective fiction and modernism were reinforced by inclusion in the Modern Library, a series that published all kinds of "modern" texts.

\section{NOTES}

${ }^{1}$ I would like to thank John Xiros Cooper, Ira Nadel and the anonymous reviewers for their helpful suggestions. I am also grateful to the Humanities Institute, University at Buffalo for offering a James Joyce fellowship that allowed me to complete the research for this article.

2 "Detective Tales and James Joyce," Hartford Courant (1 April 1928), E6.

3 Andreas Huyssen, After the Great Divide: Modernism, Mass Culture, Postmodernism (Bloomington: Indiana UP, 1986). For examples of "New Modernist Studies," see Kevin J. H. Dettmar and Stephen Watt, eds., Marketing Modernisms: Self-Promotion, Canonization, Rereading (Ann Arbor: U of Michigan P, 1996); Lawrence Rainey, Institutions of Modernism: Literary Elites and Public Culture (New Haven: Yale UP, 1998); John Xiros Cooper, Modernism and the Culture of Market Society (Cambridge: Cambridge UP, 2004); Catherine Turner, Marketing Modernism between the Two World Wars (Amherst: U of Massachusetts P, 2003); and Robert Scholes, Paradoxy of Modernism (New Haven: Yale UP, 2006). It should be noted that scholars generally examine textual interactions between "high" and "low" cultures. See R. B. Kershner, The Culture of Joyce's Ulysses (New York: Palgrave Macmillan, 2010); and Kershner, Joyce, Bakhtin, and Popular Literature: Chronicles of Disorder (Chapel Hill: U of North Carolina P, 1989). On the influence of modernist style on a crime writer such as Dashiell Hammett, see Mark McGurl, "Making 'Literature' of it: Hammett and High Culture," American Literary History 9, no. 4 (Winter 1997), 702-17; and W. R. Gray, "Jimmying the Back Door of Literature: Dashiell Hammett's Blue-Collar Modernism," Journal of Popular Culture 41, no. 5 (2008), 762-83.

${ }^{4}$ Along with David Earle, Brooks E. Hefner is one of the few to have studied the "interrelationships between detective fiction and the larger trends of literary history" in "'You've got to be Modernistic': American Vernacular Modernism, 1910-1937" (PhD diss., City University of New York, 2009). As Hefner notes, "from the side-by-side magazine publications of writers like Van Dine and Sinclair Lewis in Cosmopolitan to the Modern Library publication of Dashiell Hammett's The Maltese Falcon (1930) [sic], detective fiction has always demonstrated a strong affinity with the larger world of literary fiction" (153). The Maltese Falcon was published by Alfred Knopf in 1930, and reprinted in the Modern Library in 1934. See also Earle, Re-Covering Modernism: Pulps, Paperbacks, and the Prejudice of Form (Farnham: Ashgate, 2009) and Matthew Levay, "Remaining a Mystery: Gertrude Stein, Crime Fiction and Popular Modernism," Journal of Modern Literature 36, no. 4 (2013), 1-22.

${ }^{5}$ Book history focuses on the ways in which the meaning of a text is bound up with its publishing history and material aspect. See Robert Darnton, "What is the History of Books?" Daedalus 111, no. 3 (Summer 1982), 65-83; D. F. McKenzie, Bibliography and the Sociology of Texts (London: British Library, 1986); Leslie Howsam, Old Books and 
New Histories: An Orientation to Studies in Book and Print Culture (Toronto: U of Toronto P, 2006); and David Finkelstein and Alistair McCleery, eds., The Book History Reader, 2nd ed. (London: Routledge, 2006).

${ }^{6}$ Advertisement for "The Modern Library of the World's Best Books," New York Times (15 April 1917), BR5.

7 Jay Satterfield, The World's Best Books: Taste, Culture, and the Modern Library (Amherst: U of

Massachusetts P, 2002), p. 27. Further references will be cited parenthetically in the text.

8 Advertisement for the Modern Library, Publishers' Weekly (10 March 1928), 1028.

9 Andrew Nash, "Sifting Out 'Rubbish' in the Literature of the Twenties and Thirties: Chatto \& Windus and the Phoenix Library," in The Culture of the Publisher's Series, Vol. 1, ed. John Spiers (Basingstoke: Palgrave

Macmillan, 2011), p. 189.

10 Janet Friskney, New Canadian Library: The Ross-McClelland Years, 1952-1978 (Toronto: U of Toronto P, 2007), p. 6.

11 Robert Fraser, "Leonard Bast's Library: Aspiration, Emulation and the Imperial National Tradition," in The

Culture of the Publisher's Series, Vol. 2, ed. John Spiers (Basingstoke: Palgrave Macmillan, 2011), p. 131.

12 Kevin J. H. Dettmar, "Bookcases, Slipcases, Uncut Leaves: The Anxiety of the Gentleman's Library,"

Novel: A Forum on Fiction 39, no. 1 (Fall 2005), 20.

13 Jonathan Rose, The Intellectual Life of the British Working Classes (New Haven: Yale UP, 2001); Mary

Hammond, "'People Read so Much Now and Reflect so Little': Oxford University Press and the Classics Series," in

Reading, Publishing and the Formation of Literary Taste in England, 1880-1914 (Aldershot: Ashgate, 2006), pp. 85-

115. Further references to Rose's and Hammond's work will be cited parenthetically in the text.

${ }^{14}$ Pierre Bourdieu, The Field of Cultural Production: Essays on Art and Literature, trans. Randal Johnson

(New York: Columbia UP, 1993), p. 42.

${ }^{15}$ Box 145, Random House archives, Columbia Rare Book \& Manuscript Library (hereafter referred to as RH,

CRBM). See Satterfield, The World's Best Books, p. 42.

16 Advertisement for the Modern Library, American Mercury, 13 (Feb. 1928), xxvii (emphasis in the original).

${ }^{17}$ Advertisement for the Modern Library, Publishers' Weekly 114 (22 Sept. 1928), 1035.

${ }^{18}$ Best Ghost Stories sold 1,128 copies from January to June 1928. "Modern Library Titles in order of Sales Popularity" [1928], box 765, RH, CRBM.

${ }^{19}$ For instance, D. H. Lawrence's Sons and Lovers (included in the Modern Library in 1922) was one of the most successful titles in the series. "Modern Library Best Sellers" [1931], box 117, RH, CRBM.

${ }^{20}$ Box 131, RH, CRBM; John J. Slocum and Herbert Cahoon, A Bibliography of James Joyce, 1882-1941

(London: Rupert Hart-Davis, 1953), p. 19.

${ }^{21}$ Gordon B. Neavill, “The Modern Library Series” (PhD diss., University of Chicago, 1984), pp. 562-64.

${ }^{22}$ See Laura J. Miller, "The Best-Seller List as Marketing Tool and Historical Fiction," Book History 3 (2000), 287-304

${ }^{23}$ Likewise, John Erskine's "Great Books" program relied on the idea that "all books enshrined as 'great' were at one time recent publications intended for wide audience" and that professors of English should treat them as such. Joan Shelley Rubin, The Making of Middlebrow Culture (Chapel Hill: U of North Carolina P, 1992), p. 165.

24 Advertisement for the Modern Library, New York Times (18 Nov. 1928), BR16.

25 Barbara Loken and Deborah Roedder John, "When do Bad Things Happen to Good Brands? Understanding Internal and External Sources of Brand Dilution," in Brands and Brand Management: Contemporary Research Perspectives, ed. Barbara Loken, Rohini Ahluwalia and Michael J. Houston (New York: Psychology Press, 2010), p. 233.

26 Advertisement for the Modern Library, New York Times (20 May 1928), 65.

${ }^{27}$ Gorman later became Joyce's first biographer.

28 Herbert Gorman, introduction to A Portrait of the Artist as a Young Man (New York: Modern Library,

1928), p. x. Further references will be cited parenthetically in the text.

${ }^{29}$ This reminds us of the famous advertisement for the 1934 Random House edition of Ulysses. See Turner,

Marketing Modernism between the Two World Wars, pp. 173-213.

${ }^{30}$ Peter Pinto, "We have been Reading Lately," Canadian Jewish Chronicle (Montreal) (8 June 1928), 6.

${ }^{31}$ In addition to the five stories already mentioned, Fourteen Great Detective Stories included G. K. Chesterton's "The Blue Cross," Richard Harding Davis's "In the Fog," Melville Davisson Post's "The Age of Miracles," Robert Barr's “The Absent-Minded Coterie," Baroness Orczy's “The Fenchurch Street Mystery,” Jacques Futrelle's "The Problem of Cell 13," Samuel Hopkins Adams's "The One Best Bet," Edwin Balmer and William MacHarg's "The Private Bank Puzzle," and Owen Johnson's "One Hundred in the Dark."

32 “Crime Wave from Garden City,” Publishers' Weekly (14 April 1928), 1624.

33 Simeon Strunsky, “Cold Chills of 1928," New York Times (25 March 1928), 65.

34 Advertisement for the Crime Club, New York Times (9 Sept. 1928), 77.

35 "The psychological basis of the metropolitan type of individuality consists in the intensification of nervous stimulation which results from the swift and uninterrupted change of outer and inner stimuli." Georg Simmel, "The Metropolis and Mental Life [1903]," in The Sociology of Georg Simmel, ed. Kurt H. Wolff (Glencoe: Free P, 1950), pp. 409-10 (emphasis in the original). 
${ }^{36}$ There are many similarities between war novels and the "thrillers" of the 1920s. See Lise Jaillant, "Sapper, Hodder \& Stoughton, and the Popular Literature of the Great War," Book History 14 (2011), 137-66.

37 Arthur McKeogh and William Brown Meloney, "It's a Crime!," English Journal 18, no. 8 (Oct. 1929), 631. Further references will be cited parenthetically in the text.

${ }^{38}$ R. Gordon Kelly, Mystery Fiction and Modern Life (Jackson: UP of Mississippi, 1998), p. 13 argues that detective fiction developed as a response to the anxieties produced by modernity, such as the "suspicion and skepticism" caused by increased urbanization and immigration.

39 Raymond Chandler, "The Simple Art of Murder" (1950), http://www.en.utexas.edu/amlit/amlitprivate/scans/chandlerart.html (accessed 15 Aug. 2014)

${ }^{40}$ See Erin A. Smith, Hard-Boiled: Working-Class Readers and Pulp Magazines (Philadelphia: Temple UP, 2000). It should be noted that a high-end pulp magazine such as the Blue Book catered to a diverse audience by publishing the mystery fiction of Agatha Christie (The Man in the Brown Suit first appeared in the September 1924 issue, for example).

41 Vincent Starrett, "Introduction - Of Detective Literature," in Fourteen Great Detective Stories (New York: Modern Library, 1928), p. ix. Starrett was a journalist and detective fiction writer, who had edited Stephen Crane's Men, Women and Boats for the Modern Library in 1921.

${ }^{42}$ Dubliners was added to the Modern Library list in 1926, two years before Portrait of the Artist.

${ }^{43}$ Karen Leick, "Popular Modernism: Little Magazines and the American Daily Press," PMLA: Publications of the Modern Language Association of America 123, no. 1 (2008), 126.

44 Fanny Butcher, "Tabloid Book Review," Chicago Daily Tribune (22 April 1917), D5.

45 “Bad Taste of a New Irish Novelist." Munsey's Magazine (June 1917), 134. In 1912, Munsey's had a circulation of 400,000 and was priced at 10 cents. In 1920, its price was up at 25 cents and its circulation had dropped to 132,000. R. D. Mullen, "From Standard Magazines to Pulps and Big Slicks: A Note on the History of US General and Fiction Magazines," Science Fiction Studies 22, no. 1 (March 1995), 145.

46 “Approaches to Ulysses," Los Angeles Times (19 Nov. 1922), 11140.

47 "Books and Authors," New York Times (11 Feb. 1923), BR18.

${ }^{48}$ Thompson Kilpatrick, "Letters to the [Los Angeles] Times," Los Angeles Times (6 April 1923), 119.

49 Lucille Erskine, “James Joyce, the New Irish Immortal,” Los Angeles Times (9 Sept. 1923), XI25, illustrated magazine section.

${ }^{50}$ See $\mathrm{n} 2$.

${ }^{51}$ [Review of Portrait of the Artist], Saturday Night (Toronto, Canada) (21 April 1928), n. pag.; 'The Modern Library,' Daily Mail (Brisbane, Australia) (19 May 1928), n. pag.; 'Book Notes,' Havana Post (Havana, Cuba) (5 Feb. 1928), n. pag.

52 "Detective Tales and an Early 'James Joyce,"” Journal (Sioux City, IA) (27 May 1928), n. pag.

53 “James Joyce Book Reissued: Modern Library Publishes Portrait of the Artist as a Young Man," Spokane Daily Chronicle (29 March 1928), 10.

${ }^{54}$ The map draws on archival work at the University at Buffalo. I had access to uncatalogued newspaper clippings from the interwar period, including many reviews of the Modern Library edition of Portrait. A digital version of this map (with details for each review) is available here: http://www.lisejaillant.com/p/modern-library.html

${ }^{55}$ Gilbert Seldes, "Extra Good Ones," Dial (June 1928), 519. Further references will be cited parenthetically in the text.

56 Geraldine Pederson-Krag, "Detective Stories and the Primal Scene," Psychoanalytic Quarterly 18 (1949), 207-14; Charles Rycroft, “A Detective Story: Psychoanalytic Observations,” Psychoanalytic Quarterly 26 (1957), 22945 .

${ }^{57}$ Gilbert Seldes, "Ulysses," Nation, 115 (30 Aug. 1922), 211-12. See Michael G. Kammen, The Lively Arts: Gilbert Seldes and the Transformation of Cultural Criticism in the United States (New York: Oxford UP, 1996), p. 69. Further references to Kammen's work will be cited parenthetically in the text.

58 Gilbert Seldes, "Diplomat's Delight: Detective and Mystery Stories, Good and Bad, Passed in Review," Bookman, 66 (Sept. 1927), 91.

${ }^{59}$ The Victory Murders (New York: John Day, 1927) and The Square Emerald (New York: John Day, 1928).

${ }^{60}$ On the "coalition" between New Critics and New York Intellectuals, see Lawrence H. Schwartz, Creating Faulkner's Reputation: The Politics of Modern Literary Criticism (Knoxville: U of Tennessee P, 1988); Gerald Graff, Professing Literature: An Institutional History, 2nd ed. (Chicago: U of Chicago P, 2007) also offers a good overview of the rise of New Criticism in universities.

${ }^{61}$ Hugh Wilford, The New York Intellectuals: From Vanguard to Institution (New York: St. Martin's P, 1995), pp. 64-65.

62 Serge Guilbaut, How New York Stole the Idea of Modern Art: Abstract Expressionism, Freedom, and the Cold War, trans. Arthur Goldhammer (Chicago: U of Chicago P, 1983), p. 37.

${ }^{63}$ Wilford, The New York Intellectuals, p. 21.

${ }^{64}$ C. Wright Mills, White Collar: The American Middle Class (New York: Oxford UP, 1953), p. xi.

${ }^{65}$ Of course, the New Critics did not share this distrust of academia (although they did criticize the narrow specialization of scholars). On the construction of modernism as a difficult movement, see Leonard Diepeveen, The 
Difficulties of Modernism (New York: Routledge, 2003). On the links between modernism and professionalization, see Thomas F. Strychacz, Modernism, Mass Culture, and Professionalism (Cambridge: Cambridge UP, 1993).

66 Satterfield, The World's Best Books, pp. 146-48.

67 Harry Levin, “Toward Stendhal," Pharos 3 (Winter 1945), 71.

68 V. S. Pritchett, "Daphne Du Maurier Writes a Victorian Thriller - A London Letter," Christian Science Monitor (14 Sept. 1938), WM12.

69 James T. Farrell, "Will the Commercialization of Publishing Destroy Good Writing? Some Observations on the Future of Books," New Directions 9 (1946), 25.

70 Edmund Wilson, "Who Cares Who Killed Roger Ackroyd? [1945]," in Mass Culture: The Popular Arts in America, eds. Bernard Rosenberg and David Manning White (Glencoe, Ill.: Free Press, 1957), p. 153. Further references to Wilson's work will be cited parenthetically in the text.

${ }^{71}$ Similarly, in Fiction and the Reading Public (London: Chatto \& Windus, 1932), p. 50, Q. D. Leavis wrote about the "addiction" to detective fiction. See also W. H. Auden, "The Guilty Vicarage: Notes on the Detective Story, by an Addict," Harper's Magazine, 196 (May 1948), 406-12.

72 T. S. Eliot, "Wilkie Collins and Dickens," Times Literary Supplement (4 Aug. 1927), 525-26; André Gide, Journal, 1939-1949, Souvenirs (Paris: Bibliothèque de la Pléiade, 1954), p. 213.

73 Dwight Macdonald, "A Theory of Mass Culture [1953]," in Mass Culture: The Popular Arts in America, eds. Bernard Rosenberg and David Manning White (Glencoe, Ill: Free Press, 1957), p. 68. Further references to Macdonald's work will be cited parenthetically in the text.

${ }^{74}$ See Andrew Ross, No Respect: Intellectuals \& Popular Culture (New York: Routledge, 1989), p. 43: "the debate about mass culture was conducted in a discursive climate that linked social, cultural, and political difference to disease."

${ }^{75}$ Both Gide's The Counterfeiters and Hammett's The Maltese Falcon were published in the Modern Library (in 1931 and 1934, respectively).

${ }^{76}$ As Christopher Metress notes in The Critical Response to Dashiell Hammett (Westport: Greenwood P, 1994), p. xviii, "it is only after we move away from contemporary responses to Hammett's fiction do we see, if not a cooling of enthusiasm, then at least a warming up of critical dissent. Early on characterized almost exclusively by praise for Hammett's achievement, the critical response since then has generated an engaging, and sometimes maddening, disagreement as to the respective merits of the five novels."

${ }^{77}$ Memo, New American Library, 14 May 1951, box 18, RH, CRBM; Neavill, "The Modern Library Series," 562-64.

${ }_{78}^{78}$ Earle, Re-Covering Modernism, pp. 4, 202.

${ }^{79}$ The Signet imprint "was used to designate quality fiction, personal adventure, and reference books." John William Tebbel, A History of Book Publishing in the United States, Vol. 4 (New York: R. R. Bowker Co, 1981), p. 374.

${ }^{80}$ See Charles J. Rolo, "Simenon and Spillane: The Metaphysics of Murder for the Millions," in Mass Culture: The Popular Arts in America, eds. Bernard Rosenberg and David Manning White (Glencoe: Free Press, 1957), pp. 16575; Christopher La Farge, "Mickey Spillane and His Bloody Hammer," in Rosenberg and White, pp. 176-85. For recent scholarship on Spillane, see Peter Stanfield, Maximum Movies - Pulp Fictions: Film Culture and the Worlds of Samuel Fuller, Mickey Spillane, and Jim Thompson (New Brunswick: Rutgers UP, 2011), pp. 44-73.

${ }^{81}$ On the links between modernism, obscenity and censorship, see Allison Pease, Modernism, Mass Culture, and the Aesthetics of Obscenity (New York: Cambridge UP, 2000); and Adam Parkes, Modernism and the Theater of Censorship (New York: Oxford UP, 1996).

${ }^{82}$ For more on the ways in which paperback publishers marketed modernist writers, see Earle, Re-Covering Modernism. On the rise of paperbacks, see Kenneth C. Davis, Two-Bit Culture: The Paperbacking of America (Boston: Houghton Mifflin, 1984). For more on the New American Library, see Thomas L. Bonn, Heavy Traffic \& High Culture: New American Library as Literary Gatekeeper in the Paperback Revolution (Carbondale: Southern Illinois UP, 1989); and Tebbel, A History of Book Publishing in the United States, Vol. 4, pp. 366-79.

${ }^{83}$ According to Tebbel, NAL's ambition was to specialize in "quality paperbacks" well before the appearance of Anchor books and other "higher priced trade lines" (374).

${ }^{84}$ Advertisement for The Fair [department store], Chicago Daily Tribune (10 Nov. 1953), 6.

85 Delmore Schwartz, "Masterpieces as Cartoons [1952]," in Arguing Comics: Literary Masters on a Popular Medium, eds. Jeet Heer and Kent Worcester (Jackson: UP of Mississippi, 2004), pp. 52-53.

${ }^{86}$ See Alistair Stead, "Joyce on the Case: 'Supposing that it was His Own Case He Told...,", in James Joyce Studies in Italy 7: The Benstock Library as a Mirror of Joyce, ed. Rosa Maria Bollettieri Bosinelli (Rome: Bulzoni, 2002), pp. 147-66; Richard Brown, "More 'Sherlockholmesing' in Joyce's Ulysses," Notes and Queries 55, no. 1 (2008), 66-68; and William D. Jenkins, The Adventure of the Detected Detective: Sherlock Holmes in James Joyce's Finnegans Wake (Westport: Greenwood P, 1998).

${ }^{87}$ Kershner, The Culture of Joyce's Ulysses, p. 7.

${ }^{88}$ Suzanne Ferguson, “A Sherlook at 'Dubliners': Structural and Thematic Analogues in Detective Stories and the Modern Short Story," James Joyce Quarterly 16, no. 1/2 (1978), 114.

89 A. Conan Doyle, "The Red-Headed League," in Fourteen Great Detective Stories, ed. Vincent Starrett (New York: Modern Library, 1928), p. 46. 